\title{
MARCIN MACIOŁEK
}

(D) https://orcid.org/0000-0002-9147-1283

Uniwersytet Śląski w Katowicach

Katowice

\section{O biegunie - językoznawczo (rozważania w kontekście tytułu powieści Olgi Tokarczuk Bieguni)}

\author{
On biegun - linguistically speaking \\ (deliberations in the context of the title of \\ Olga Tokarczuk's novel Bieguni/Flights)
}

\begin{abstract}
The paper contains a historical linguistic analysis of the noun biegun. It was prompted by the inflectional form of the plural nominative bieguni, the title of one of Olga Tokarczuk's novels, a form unusual from the point of view of the contemporary Polish grammatical system. Tokarczuk used the form ending in $-i$, typical of masculine personal nouns, while the word biegun is commonly known to be used nowadays only in meanings that do not refer to people. This is why the paper attempts to gain insight into the semantics of the lexeme biegun in the history of the Polish language. The research carried out made it possible to determine that the examined unit used to function in many personal meanings in the past, meanings that would eventually become obsolete with the gradual lexicalization of the word biegun and in relation the appearance of its derivational synonyms in the Polish language. Tokarczuk thus revived some of the old meanings of the word biegun referring to people, and at the same time brought out new, metaphorical meanings embedded in it in potentia - thus delexicalizing the examined unit.
\end{abstract}

Key words: biegun, lexicalization, delexicalization, -un affix, masculine personal nouns

Tytuł książki Olgi Tokarczuk wydanej po raz pierwszy w 2007 roku nakładem Wydawnictwa Literackiego i nagrodzonej Nike - Bieguni - przykuwa uwagę czytelników. Dzieje się tak za sprawą jego nietypowej formy gramatycznej - jest to mianownik liczby mnogiej z końcówką - $i$, nie zaś - $y$, której spodziewałby się współczesny Polak, mając na myśli pluralną postać rzeczownika biegun. Ku zaskoczeniu odbiorców pisarka użyła końcówki -i, będącej typowym wykładnikiem fleksyjnym mianownika liczby mnogiej rze- 
czowników męs k o o s o bow y ch, których temat (wyławiany w dopełniaczu liczby pojedynczej) ${ }^{1}$ kończy się spółgłoską twardą (z wyjątkiem tylnojęzykowych $[\mathrm{k}]$ i $[\mathrm{g}]$ oraz przedniojęzykowych sonornych $[\mathrm{r}]$ i $[1])^{2}$; przy czym palatalizujący wpływ tej końcówki (jest nią wszak samogłoska przednia) powoduje wymiany spółgłoskowe (którym nieraz mogą też towarzyszyć alternacje samogłoskowe), por.: sqsiedzi (ale: sqsiad-a), piraci (ale: pirat-a), Francuzi (ale: Francuz-a), prezesi (ale: prezes-a), Kaszubi (ale: Kaszub-a), biskupi (ale: biskup-a) czy wreszcie blondyni (ale: blondyn-a), dziekani (ale: driekan-a), kretyni (ale: kretyn-a), paulini (ale: paulin-a). Z kolei zakończone spółgłoską twardą (oprócz [k], [g], [1]) rzeczowniki nie męs ko os obowe (tj. męskorzeczowe i męskozwierzęce) - a do takich w świadomości przeciętnych użytkowników języka polskiego należy wyraz biegun - winny przyjmować końcówkę -y, por.: samochody, gepardy, pistolety, koty, obrazy, plazy, dtugopisy, psy, chleby, kraby, stupy, sepy, pioruny, rekiny33 (zob. np. Jadacka 2006, 19). To właśnie z tego powodu, tj. za sprawą końcówki -i, która jest wyrazistym sygnałem rodzaju męskoosobowego, forma M. Im bieguni, stanowiąca tytuł powieści Olgi Tokarczuk, zadziwia współczesnych Polaków, którzy wyraz biegun kojarzą wyłącznie z sensami nie(męsko)osobowymi, a mianowicie jako leksem nieod-

$1 \mathrm{~W}$ tym miejscu warto przypomnieć, że zgodnie $\mathrm{z}$ tradycyjnym podejściem za temat podstawowy rzeczownika uznaje się temat D. lp (zob. np. Strutyński 1994, 62), nie zaś - jak przyjmują autorzy niektórych nowszych opracowań gramatyki języka polskiego - temat M. lp. O tym, że klasyczne ujęcie jest rozwiązaniem lepszym, przekonujemy się, tworząc choćby formy Ms. lp rzeczowników męskich zakończonych spółgłoską wargową. Zgodnie z zasadami rozdziału końcówek fleksyjnych w tym przypadku końcówkę -e przyjmuja rzeczowniki twardotematowe, a - $u$ - miękkotematowe. Gdyby więc uznać, że temat rzeczownika wyławiamy w M. lp, od rzeczowników typu: gołab, jastrz̨qb, karp, paw, ்́ótw, a także nazw własnych, takich jak np. Bytom, Ośnięcim, Wrocław musielibyśmy tworzyć formy Ms. *(o) gołębie, jastrzębie, karpie, pawie, źótwie, *(w) Bytomie, Oswięcimie, Wroctawie, analogicznie jak (o) zebie, dębie, sklepie, stawie, (w) Chetmie, Krakowie. W związku z tym jedynie poprawne formy: (o) gołębiu, jastrz̨biu, karpiu, pawiu, źólwiu, (w) Bytomiu, Oświęcimiu, Wrocławiu - w świetle takiego kryterium - trzeba by uznać za wyjątki od reguły (a wyrazy gołab, jastrzqab, karp, paw, źótw, Bytom, Oświęcim, Wroclaw za rzeczowniki pozornie twardotematowe). Przyjęcie tematu D. lp za temat podstawowy rzeczownika pozwala tego typu komplikacji uniknąć.

2 Rzeczowniki męskoosobowe o temacie zakończonym spółgłoskami $[\mathrm{k}],[\mathrm{g}],[\mathrm{r}]$ przybierają w M. lm końcówkę - $y$, której dodaniu towarzyszą odpowiednio wymiany $[\mathrm{k}]:[\mathrm{c}],[\mathrm{g}]:[\mathrm{z}]$ i [r] : [ž], por. fizycy, chemicy, biolodzy, szpiedzy, lektorzy, szoferzy, zaś rzeczowniki o temacie na [1] mają w M. Im końcówkę -e, por. nauczyciele, drwale.

${ }^{3}$ Rzeczowniki niemęskoosobowe, których temat fleksyjny zakończony jest spółgłoskami tylnojęzykowymi [k] i [g], mają w M. lm końcówkę -i, por. pisaki, niedźwiadki, rogi, głowonogi, zaś o temacie na [1] przybierają końcówkę -e, por. hotele, szakale. 
noszący się do mężczyzn czy w ogóle do ludzi, ani nawet do zwierząt, a zatem postrzegają go jako rzeczownik nieżywotny (ściślej: męskorzeczowy). Odmienną dystrybucję końcówek - $i$ oraz - $y$ w M. lm masculinów - zależną od znaczenia i rodzaju męsko- czy niemęskoosobowego leksemów rzeczownikowych - dobrze uzmysławia fakt współwystępowania w polszczyźnie par fleksyjnych typu: pampersi ${ }^{4}$ - pampersy, komandosi-komandosy ${ }^{5}$, agenciagenty, klienci - klienty ${ }^{6}$, pasożyci - pasożyty, Krzyżacy - krayżaki, Prusacy - prusaki, szkodnicy - szkodniki, przewodnicy - przewodniki, plywacy - plywaki itp., w których końcówki wskazują na różnice w obiektywnej semantyce, unaoczniając przeciwstawienie znaczenia osobowego - nieosobowemu, tj. opozycję homo - animal lub homo - res ${ }^{7}$. W tę serię wpisuje się także morfologiczny duet bieguni - bieguny. Użycie przez Tokarczuk formy bieguni intryguje tym samym czytelnika i skłania go do poszukiwania innych niż te, do których przywykł, sensów rzeczownika biegun, ściślej: znaczeń osobowych. Istotną

${ }^{4}$ Pampersi to 'prawicowi dziennikarze zgrupowani wokół Wiesława Walendziaka w okresie, gdy pełnił on funkcję szefa Telewizji Polskiej, tj. w latach 1993-1996, mający wpływ na media, zwłaszcza na telewizję'. W polszczyźnie potocznej jest to także określenie 'ludzi młodych o niewielkim doświadczeniu zawodowym, lecz pełnych ambicji i przekonanych o swojej nieomylności' (por. https://sjp.pl/pampersy [dostęp: 28.01.2020]).

$5 \mathrm{~W}$ polszczyźnie potocznej i żargonie młodzieżowym komandos to także określenie taniego wina.

${ }^{6}$ Zarówno klienty, jak i agenty oznaczają rodzaj oprogramowania komputerowego (podobnie asystenty, keatory, edytory itp.).

7 Przeciwstawienie znaczenia osobowego i nieosobowego jest wyraziście sygnalizowane fleksyjnie również w D. lp w takich parach wyrazowych, jak: kantora 'śpiewaka kościelnego' kantoru 'punktu wymiany walut', tenora 'śpiewaka' - tenoru 'głosu', zbiega 'uciekiniera, dezertera' - zbiegu 'przypadku, koincydencji; miejsca zetknięcia', prymitywa 'człowieka prymitywnego, prostaka' - prymitymu 'rzeczy prymitywnej', oryginala 'człowieka oryginalnego' - oryginatu 'rzeczy oryginalnej', geniusza 'osoby inteligentnej' - geniuszu 'talentu' (wykładnikiem morfologicznym sensu osobowego jest tu każdorazowo końcówka - $a$, a nieosobowego - $-u$ ). Dla porządku należy jeszcze zaznaczyć, że ponieważ w parach typu bieguni - bieguny, jak i zbiega - zbiegu zróżnicowaniu formalnemu towarzyszy zróżnicowanie funkcjonalne (odmienne znaczenie), nie można mówić tu o formach obocznych, a zatem nie są to bynajmniej przykłady wariantywności fleksyjnej; tego typu pary można by określić raczej jako „pseudowarianty” czy „niby-warianty" (zob. Ruszkowski 2018, 11).

Różnicowanie końcówek -i oraz -y w M. lm rzeczowników męskoosobowych wtórnie może być wykorzystywane do wyrażania stosunku nadawcy względem osoby nazwanej danym rzeczownikiem, z czym wiąże się zróżnicowanie na formy neutralne (niedeprecjatywne), np. studenci, policjanci, atleci, urzednicy, filolodsy, biznesmeni, kaplani, i nacechowane (deprecjatywne), por. studenty, policjanty, atlety, urz̨lniki, filologi, biznesmeny, kapłany (więcej o kategorii deprecjatywności pisze Saloni 1988). 
w tym względzie wskazówkę interpretacyjną odnajdujemy w komentarzu (opisie) promocyjnym wydawcy zamieszczonym na tylnej okładce powieści:

Bieguni - odłam prawosławnych starowierców. Odrzucali hierarchię kościelna, wierzyli, że świat jest przesiąknięty złem. Uważali, że zło ma największą moc, gdy człowiek stanie w miejscu. Jedynym sposobem ratunku przed złem jest podróż, ruch.

Kim są współcześni „bieguni”?

Jak wielu jest ich wśród nas?8

(Tokarczuk 2007, tylna okładka)

Wydaje się jednak, że leksem biegun, występujący w tytule powieści Tokarczuk, jest nie tylko desygnatem odłamu rosyjskich staroobrzędowców, którzy uważali, że nieustanne przemieszczenie się chroni człowieka przed złem, którym przeniknięty jest świat. Choć ich filozofia myślenia bez wątpienia wywarła niemały wpływ na wyobraźnię literacką artystki, to jednak trzeba zauważyć, iż motywowanie tytułu książki nawiązaniami do światopoglądu prawosławnych biegunów (jak sugeruje wydawca i jak w związku z tym często się (zyni ${ }^{9}$ ) nie może być jedyną jego wykładnią. W dziele noblistki, już od pierwszych stron, daje się zauważyć niebywała fascynacja ruchem w ogóle, ruchliwościa jako taką (zarówno tą przestrzenna, jak i umysłowa, intelektualna), ustawicznym przemieszczaniem się ludzi oraz idei, ciagłym byciem w podróży. Tak ważna dla tego utworu kategoria mobilności (by użyć modnego dziś słowa) pozwala, jak się zdaje, doszukiwać się także innej, niż przywołana, motywacji tytułu Bieguni; nakazuje zarazem postawić pytanie o ukryte (naddane?) znaczenia leksemu biegun. Gwoli ścisłości już wstępnie należy nadmienić, że próbę rozeznania się w semantyce rzeczownika biegun przed kilkunastu laty podjęła Jadwiga Waniakowa w związku z prowadzo-

\footnotetext{
${ }^{8} \mathrm{~W}$ przypadku kolejnych wydań utworu opis wydawcy ma następująca postać:

Co mamy wspólnego z biegunami - prawosławnym odłamem starowierców, ludźmi, którzy zło oswajają ruchem? Ile jest w nas z biegunów?

Od dawnych sułtańskich pałaców przez siedemnastowieczne gabinety osobliwości po współczesne hale odlotów - Olga Tokarczuk zabiera czytelników w niezwykłą podróż przez różne miejsca i czasy. Zaprasza do wspólnego oswajania migotliwej, fragmentarycznej rzeczywistości, do porzucania utartych szlaków.

Ta powieść nie ma granic - dzieje się na całym świecie (Tokarczuk 2018, tylna okładka).

9 Zob. np. https://kultura.onet.pl/wiadomosci/olga-tokarczuk-laureatka-miedzynarodo wej-nagrody-bookera/vvwyrcg oraz https://wyborcza.pl/1,75410,5217684,Dwudziestka _po_raz_dwunasty.html [dostęp: 29.01.2020].
} 
nymi przez siebie badaniami nad kształtowaniem się polskiej terminologii astronomicznej (Waniakowa 2002; zob. też Waniakowa 2003a, 2003b). Kluczowe w jej dociekaniach było jednak ustalenie czynników, które zadecydowały o pojawieniu się terminologicznego - geograficznego - sensu rozpatrywanej jednostki. Kwestię tę badaczka analizowała, uwzględniając również znaczenia innosłowiańskich odpowiedników formalnych polskiego wyrazu biegun oraz $\mathrm{w}$ porównaniu $\mathrm{z}$ jego greckim ekwiwalentem semantycznym

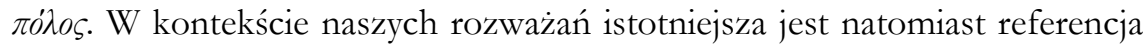
osobowa rozpatrywanej nazwy.

Wyraz biegun jest kontynuantem prasłowiańskiej formy *bĕgunz, która z punktu widzenia słowotwórstwa historycznego jest derywatem dewerbalnym utworzonym od psł. podstawy *běg(a)ti, *běžati (pol. biec, bię̧̇ec) za pomoca przyrostka $*_{- \text {-unz }}^{10}$. Wykorzystany w tym akcie słowotwórczym formant afiksalny - jak podaje Franciszek Sławski $(2011,113)$ - służył przede wszystkim do tworzenia nazw agentywnych, o czym świadczą m.in. również następujące formacje: psł. *pěstunъ 'piastun' $\leftarrow$ *pèstiti 'pieścić', płnsłow. *opekun ‘opiekun' $\leftarrow$ *opekti, *opekati ‘opiekować się', płnsłow. *̌̌bruns ‘żarłok' $\leftarrow$ *̌̌zrrq, žerti 'żreć', płnsłow. *chvastuns 'papla, gaduła; człowiek chełpiący się' $\leftarrow$ * chvastiti 'paplać, gadać, chełpić się', wschsł. *klikunz 'krzykacz; ten, kto krzyczy' $\leftarrow$ *kliketi, klikati 'krzyczeć', wchsł. *védunz 'znachor, wróżbita' $\leftarrow{ }^{*}$ védèti 'wiedzieć', zachsł.-płdsł. *zъdunz 'zdun; garncarz' $\leftarrow{ }^{*}$ zid'o, zbdati 'lepić, kształtować', płdsł.-wschsł. *èdunъ 'kto dużo je’ $\leftarrow$ *èmъ, èsti 'jeść' (Sławski 2011, 113-114; zob. też: Wojtyła-Świerzowska 1974, 56-61). Z przytoczonych przykładów wynika - na co (o ile mi wiadomo) dotychczas nie zwracano uwagi - że przyrostek *-unъ (w prasłowiańszczyźnie i jej dia-

$10 \mathrm{O}$ prasłowiańskim rodowodzie analizowanej jednostki świadczą występujące - dawniej lub współcześnie - w innych językach słowiańskich (należących, co istotne, do wszystkich trzech grup, tj. zachodniej, wschodniej i południowej), zbliżone do niej pod względem formalnym i semantycznym, odpowiedniki, por.: stczes. běbún 'biegacz; włóczęga; uciekinier', czes. běhoun 'biegacz, posłaniec, goniec; koń wyścigowy', 'obracające się części urządzeń; górny kamień młyński'; ros. бегý [begún] 'biegacz, goniec', 'kamień młyński', ukr. бizýn [bigún] 'ktoś, kto, szybko biega; biegacz', 'oś w drzwiach, we wrotach' (też ukr. бizyнú [biguný] 'żarna, kamienie do rozcierania ziarna'), brus. бягун [bjagun] 'ten, kto szybko biega; biegacz', daw. słoweń. begûn 'uciekinier', daw. serb.-chorw. bjègūn (dziś бizýn [bigún] tylko rozszerzone morfologicznie, tj. z dodatkowym przyrostkiem, chorw. bjegúnac i serb. бezýmau [bjegúnac]) 'zbieg, uciekinier, dezerter' - wykaz form i znaczeń ekwiwalentów innosłowiańskich polskiego wyrazu biegun podaję na podstawie danych zawartych w słownikach internetowych oraz materiału językowego przytaczanego przez Wiesława Borysia (2005, 27) i Marię Wojtyłę-Świerzowską $(1974,57)$. 
lektach) służył do derywowania głównie nazw osobowych wykonawców czynności; w znacznie bardziej ograniczonym zakresie używany był natomiast do tworzenia nazw subiektów nieosobowych, jak np. psł. *perunz 'piorun' $\leftarrow$ *perq, pbrati 'bić, uderzać, razić'11 czy *peluns 'piołun' $\leftarrow$ *poléti 'płonać, gorzeć' (derywat onomazjologiczny; zapewne od gorzkiego, palącego smaku tak nazwanej rośliny). Również wiele późniejszych, powstałych już na gruncie poszczególnych języków słowiańskich, tego typu nominów agentis odnosi się do osób, por. np. ukr. брехýн 'łgarz, kłamca' $\leftarrow$ бpexamu 'kłamać; szczekać', ros. coným 'ten, kto ciężko sapie, dyszy' $\leftarrow$ conéms 'sapać', крикy' 'krzykacz; ten, kto dużo krzyczy' $\leftarrow$ кuчáms 'krzyczeć', czes. mlsoun 'łakomczuch' $\leftarrow$ mlsati 'delektować się jedzeniem', czes. ŕvoun 'krzykacz' $\leftarrow$ rváti 'ryczeć, wyć', czes. šplhoun 'kto się wspina' (w slangu studenckim metaforycznie 'kujon') $\leftarrow$ šplhati 'piąć się, wspinać się’ (w żargonie 'kuć). Hipotezę tę (przynajmniej w pewnym stopniu) może także, jak sądzę, pośrednio potwierdzać sygnalizowany przez Marię Wojtyłę-Świerzowską (szerzej jednak przez tę badaczkę niekomentowany) fakt, iż ,formacje na *-unъ bardzo często odznaczaja się silnym (ujemnym) zabarwieniem emocjonalnym, co widoczne jest zwłaszcza w dialektycznym materiale rosyjskim i ukraińskim" (Wojtyła-Świerzowska 1974, 60). Rozszerzający się stopniowo zakres użycia formantu -un (pochodzącego od psł. *-unz), stosowanego w coraz większym stopniu do tworzenia nie tylko osobowych, lecz także nieosobowych nazw wykonawców czynności, sprawił, że wtórnie wykorzystywany był on do derywowania nazw narzędzi, a zatem obok funkcji agentywnej zaczął też pełnić funkcję instrumentalna, tj. oznaczania środka czynności (w wielu derywatach obie te funkcje się nakładaja, co wiąże się z wieloznacznością tego typu formacji $)^{12}$. Dla pełni obrazu trzeba dodać, że omawiany typ słowo-

${ }^{11}$ Choć interpretacja słowotwórcza nazwy *perunъ nie nastręcza na pozór trudności na gruncie słowiańskim, to jednak nie wszyscy badacze są zgodni z przedstawioną wykładnią. Według Aleksandra Brücknera forma piorun, tj. z interesującym nas przyrostkiem -un, jest wtórna i została urobiona na wzór kluczowego dla naszych rozważań wyrazu biegun od dawnego pieryn, pochodzącego z wcześniejszego *pierkyn (zob. Brückner 1985, 414, por. też Wojtyła-Świerzowska 1974, 57-59).

12 Przejmowanie funkcji instrumentalnej przez formanty wykorzystywane prymarnie do tworzenia (nieosobowych) nazw wykonawców czynności to zresztą z punktu widzenia słowotwórstwa historycznego zjawisko zupełnie naturalne, często spotykane. Związana z tym wielofunkcyjność formantów (nakładanie się, przenikanie się obu tych funkcji) skutkuje w wielu przypadkach niemożnością jednoznacznego rozstrzygnięcia, czy dany derywat należy do kategorii nomina agentis czy nomina instrumenti, innymi słowy: zaciera się (neutralizuje się) różnica między nazwami subiektów i nazwami narzędzi (zob. Grzegorczykowa, Laskowski, Wróbel, 
twórczy nie jest w słowiańszczyźnie, ogólnie rzecz ujmując, zbyt produktywny. Wyjątek w tym zakresie stanowią wyłącznie języki wschodniosłowiańskie (szczególnie dialekty rosyjskie i ukraińskie) oraz - choć w nieco bardziej ograniczonym stopniu - język czeski. Spośród języków południowosłowiańskich najwięcej tego typu derywatów odnotowano w słoweńskim (zob. Sławski 2011, 114; Wojtyła-Świerzowska 1974, 60). Także w polszczyźnie formacje z przyrostkiem -un nie były dawniej i nie są współcześnie zbyt liczne. W materiale językowym wyekscerpowanym ze Stownika staropolskiego (SStp) mamy zaledwie trzy rzeczowniki z -un o wyraźnej motywacji formalnej i semantycznej; sa to wyrazy: biegun, opiekun i piastun ${ }^{13}$. W polszczyźnie XVI wieku, oprócz wymienionych, pojawiają się cztery kolejne odczasownikowe nazwy wykonawców czynności, a mianowicie: ciekun 'goniec, posłaniec' $\leftarrow$ ciec 'biec', śpiegun || szpiegun 'funkcjonariusz służby śledczej' i 'urzędnik przeprowadzający pobór do wojska' $\leftarrow$ spiegować || szpiegować (neologizm wprowadzony przez Jana Mączyńskiego w dziele Lexicon latino-polonicum), zbiegun 'zbieg' $\longleftarrow$ zbiec, zbiegać (utworzony zapewne przez analogię do bieguna) oraz zdun, który już wcześniej się zleksykalizował wskutek zatraty w polszczyźnie jego podstawy czasownikowej, pochodzącej od psł. *zid'Q, zbdati (zob. Pepłowski 1974, 275-276)14. W kolejnych stuleciach liczba formacji z przyrostkiem -un nieznacznie wzrasta (zob. tabela 1.). W XVII stuleciu pojawia się szeptun 'ten, kto leczy zamawianiem; znachor' $\leftarrow$ szeptać. Zarejestrowane w Elektronicznym stowniku jezyka polskiego XVII i XVIII wieku (ESJP XVII-XVIII) rzeczowniki piekun oraz mypiekun, nienotowane w póź-

red., 1984, 341). Problem nieostrości granic między tymi obiema kategoriami słowotwórczymi i sensownością wydzielania tej drugiej, tj. nominów instrumenti, był wielokrotnie dyskutowany zarówno z pozycji metodologii strukturalnej, jak i kognitywnej. Syntetycznie omawia to zagadnienie Katarzyna Kuligowska (2018, 7-15).

${ }^{13}$ Jako słowa o zatartej już w okresie staropolskim motywacji należałoby uznać zarejestrowane w SStp rzeczowniki piołun, piorun i tarbun; z kolei notowany w tym leksykonie wyraz podpiastun 'opiekun, wychowawca' to prawdopodobnie derywat prefiksalny od piastun (por. Kleszczowa, red., 1996, 191 i 300).

14 Por. też http://spxvi.edu.pl/indeks/szukaj/?tryb=2\&q=un\&typ=\&porzadek=0 [dostęp: 31.01.2020]. Notowany w Stowniku polszczyzny XVI wieku wyraz przebiegun 'poprzednik' należałoby interpretować jako rzeczownik prefigowany od słowa biegun. Podwójna interpretację słowotwórczą można natomiast przypisać również zarejestrowanemu w tym leksykonie wyrazowi powrozobiegun 'linoskoczek' - można uznać go albo za rzeczownik złożony utworzony za pomocą interfiksu -o- od wyrazów powrózi i biegun, a zatem o strukturze $\mathrm{N}\left(\mathrm{N}_{1}+\mathrm{N}_{2}\right)$, albo za złożenie typu $\mathrm{N}\left(\mathrm{N}_{1}+\mathrm{V}\right)$ utworzone za pomocą złożonego formantu interfiksalno-sufiksalnego, tj. wrostka -o- oraz przyrostka -un, na bazie słów powrózi i biegać. 
niejszych leksykonach (poza wyrazem wypiekun w SL, zob. przyp. 15.), to nacechowane ekspresywnie neologizmy, użyte okazjonalnie przez Kazimierza Opalińskiego w jego Satyrach albo przestrogach, por.: „Nie wspominam tutorów, których piekunami/ Albo wypiekunami, nie opiekunami/ Słusznie nazwać, bo pewnie wypieką ostatek,/ I wysuszą dostatki dzieci pozostałych,/ Że kropla nie zostanie ojcowskiego zbioru" (Opaliński 1840, 177) ${ }^{15}$. Aktywność formantu -un wzrasta nieco, począwszy od XIX wieku, a zwłaszcza w drugiej połowie tego stulecia i na początku wieku następnego. W polszczyźnie pojawiają się wówczas formacje: najpierw zwiastun $\leftarrow$ żiastować (początkowo funkcjonujący wyłącznie w znaczeniu osobowym, czyli jako 'ten, co zwiastuje; posłannik, goniec'), a następnie chapun 'trudniący się u żydów wykrywaniem i łowieniem zbiegów' i 'potajemnie biorący obce rzeczy' chapać 'capnacć, nagle porwać' (definicje według SWil) oraz skakun 'skakacz; chyżoskacz' i '(w szachach) figura przedstawiająca konia, nazwana stąd, iż robi przeskoki, in. konik’ (znaczenie za: SWil) $\leftarrow$ skakać, a dalej szcrzekun 'zwierzę, które szczeka; szczekacz, pies' $\leftarrow$ szçekać i wreszcie notowany po raz pierwszy w SJPD wrzaskun 'ten, kto robi wrzask, głośno krzyczy; krzykacz’, w przeciwieństwie do pozostałych derywatów - na co wskazuje przytoczona definicja - motywowany (najpewniej) nie czasownikiem, lecz rzeczownikiem wrzask ${ }^{16}$. Na tym w zasadzie wyczerpuje się lista formacji utworzonych w języku polskim za pomocą przyrostka -un. Nowych wyrazów pochodnych derywowanych z jego udziałem nie zarejestrowała już chociażby Hanna Jadacka, gdy opisywała system słowotwórczy polszczyzny lat 1945-2000 (zob. Jadacka 2001); nie pojawiły się one także po roku 2000. Tak więc omawiany typ słowotwórczy (tzn. nazwy subiektów z sufiksem un) trzeba uznać za współcześnie już nieproduktywny.

Spróbujmy teraz odnieść sformułowane dotychczas uwagi na temat formantu -un i derywowanych za jego pomocą nazw do interesującego nas leksemu. Otóż polski rzeczownik biegun, którego źródło tkwi w psł. *běgunz,

${ }^{15}$ Rzeczownik mypiekun uwzględnia też Samuel Bogumił Linde w swoim Stowniku jezyłka polskiego (SL) i definiuje go (zgodnie z intencją twórcy tego neologizmu) jako 'niesprawiedliwy, małoletnich krzywdzący opiekun' oraz opatruje gwiazdką jako wyraz już nieużywany.

16 Zarejestrowane w SJPD wyrazy brzechun 'szczekacz; kundel', kryykeun 'krzykacz' oraz widun 'jasnowidz, wieszcz', notowane już wcześniej w SWil i/lub SW, a nieuwzględnione w tabeli 1. oraz w przeprowadzonej analizie, są zapożyczeniami z języków wschodniosłowiańskich (ukraińskiego lub rosyjskiego). Podzielność i motywacja słowotwórcza tych dwóch ostatnich jest, jak się wydaje, wtórna - powstała wskutek zbieżności fonetycznej ich podstaw rodzimych z odpowiednimi czasownikami polskimi, tj. widzieć i krayyczéć. 
w świetle przedstawionych faktów jest formacją słowotwórczą powstałą na bazie czasownika biec, biegać (psł. *bègti, *bègati) 'biec; krążyć, obracać się’ przy udziale sufiksu -un (psł. *-unz), wyspecjalizowanego przede wszystkim w tworzeniu nazw osobowych wykonawców czynności. Jego pierwotne, wywiedzione z budowy słowotwórczej (tj. strukturalne), znaczenie było zatem następujące: 'ten, kto biega, biegnie'. W związku z rozszerzeniem funkcji formantu -un także na subiekty nieosobowe wyraz biegun z czasem zaczął również oznaczać 'to, co biega' i wreszcie 'to, za pomocą czego coś biega', tj. 'różne poruszające się, obracające się części urządzeń'. W ten sposób funkcja (wartość semantyczna) agentywna splotła się z instrumentalną, a biegun mógł być interpretowany zarówno jako nazwa (osobowego i nieosobowego) wykonawcy czynności, jak i nazwa narzędzia. Tak nakreślona ewolucja semantyczna leksemu biegun znajduje odzwierciedlenie w materiale tekstowym i słownikowym.

Tabela 1. Rzeczowniki z przyrostkiem -un w języku polskim (na podstawie materiału słownikowego)

\begin{tabular}{|c|c|c|c|c|c|c|c|}
\hline & SStp & SXVI & 离离 & SL & SWil & SW & SJPD \\
\hline biegun & + & + & + & + & + & + & + \\
\hline ciekun & & + & & & + & + & + \\
\hline chapun & & & & & + & + & \\
\hline opiekun & + & + & + & + & + & + & + \\
\hline piastun & + & + & + & + & + & + & + \\
\hline piekun & & & + & & & & \\
\hline skakun & & & & & + & + & + \\
\hline szczekun & & & & & & + & + \\
\hline szeptun & & & + & & & + & + \\
\hline śpiegun & & + & & + & + & + & \\
\hline wrzaskun & & & & & & & + \\
\hline wypiekun & & & + & + & & & \\
\hline zbiegun & & + & & + & + & & \\
\hline zwiastun & & & & + & + & + & + \\
\hline
\end{tabular}

W zachowanych tekstach staropolskich wyraz biegun występuje rzadko. Jego najstarsze poświadczenia pochodza z drugiej połowy XV wieku. Dwukrotnie użyto go w Biblii królowej Zofii, a także dwa razy zanotowano w formie glos w wydrukowanym w 1490 roku słowniku łacińsko-niemieckim pn. 
Vocabularius ex quo ${ }^{17}$. Ponadto raz pojawia się w Mamotrekcie kaliskim z 1471 roku. Choć najstarsze przykłady użycia (poświadczenia tekstowe) leksemu biegun są dość skromne, pozwalaja - z uwagi na swój charakter (ekwiwalenty tłumaczeniowe) bądź wyrazisty kontekst, w którym rzeczownik ten występuje - ustalić precyzyjnie jego znaczenie (a właściwie znaczenia). Otóż, w najdawniejszym okresie rozwoju polszczyzny (dobie staropolskiej) biegun używany był wyłącznie w odniesieniu do osób i oznaczał:

- 'gońca' (łac. cursor), por.:

Przeto pospyeszily sy $\phi$ by egunowye z lysti, podle przikazanya krolyowa y yego ksy z t, ku wszemu Israhelu a ku Iudowu pokolenyu, iako bil krol przikazal (BZ II Par 30, 6, cyt. za: Małecki, oprac., 1871, 273; podkr. - M.M.)

Przeto byezely r $\phi$ cze byegunowye, myasto od myasta, po zemy Efraymowye a Manasowye, az do zemye Zabulonowye, a ony sy gym posmyewaly a klamaly gymy (BZ II Par 30, 10, cyt. za: Małecki, oprac., 1871, 273; podkr. - M.M. $)^{18}$

cursor - czyekącz, by egvn (glosa z Vocabularius ex quo, za: Erzepki 1908, 3; podkr. - M.M. $)^{19}$

- 'włóczęgę' (łac. homo vagus), por.:

pedivagus - byegvn (glosa z Vocabularius ex quo, za: Erzepki 1908, 3; podkr. - M.M. $)^{20}$

17 Polskie glosy zapisane w tym wokabularzu zebrał i uporządkował alfabetycznie, a następnie opublikował w 1908 roku Bolesław Erzepki w „Rocznikach Towarzystwa Przyjaciół Nauk Poznańskiego" (w tomie XXXIV). Sam słownik dostępny jest natomiast on-line w zbiorach kilku bibliotek cyfrowych, m.in. w Śląskiej Bibliotece Cyfrowej (pod adresem https://sbc.org.pl/dlibra/ publication/58338/edition/54823/content) oraz Wielkopolskiej Biblioteki Cyfrowej (pod adresem https://www.wbc.poznan.pl/dlibra/show-content/publication/edition/408191?id=408191).

Niestety, żaden $\mathrm{z}$ udostępnionych $\mathrm{w}$ internecie egzemplarzy inkunabułu nie jest tym, na którym pracował Erzepki.

${ }^{18}$ Lokalizację cytatu w zabytku podaję według Stownika staropolskiego, jednak w odróżnieniu od tego źródła przytaczam szerszy kontekst, w którym pojawia się interesująca nas jednostka, za wydaniem Biblii królowej Zofii opracowanym przez Antoniego Małeckiego. W transliteracji przywołane wyimki wyglądają następująco: Przeto pośpieszyli się biegunowie z listy, podle prayykazania królowa i jego ksiażat, ku wszemu Izraelu a ku Judowu pokoleniu, jako byt król praykazat (BZ II Par 30, 6) oraz Prz̧eto bieżeli racze biegunowie, miasto od miasta, po ziemi Efraimowie a Manasowie, aż. do ziemie Zabulonowie, a oni sie jim pośmiewali a kłamali jimi (BZ II Par 30, 10).

${ }^{19} \mathrm{~W}$ transliteracji: cursor - ciekacæ, biegun.

$20 \mathrm{~W}$ transliteracji: pedivagus - biegun. 
- 'odstępcę od wiary, apostatę' (łac. profugus, apostata), por.:

apostata - byegvn a. nyevstaviczny (glosa/hasło z Mamotrektu kaliskiego, za: Żurawska-Górecka, Kyas, oprac., 1978, 134, por. Loś 1912, 67; podkr. - M.M.) $)^{21}$.

Frekwencja użycia rzeczownika biegun wzrasta wydatnie (przynajmniej w świetle danych leksykograficznych) w XVI stuleciu. Twórcy SPXVI odnotowali 35 jego wystapień. Znane już w średniowieczu sensy: 'goniec, posłaniec, posłaniec odnoszący listy' oraz 'tułacz, obieżyświat, bezdomny, włóczęga, koczownik, hultaj; wygnaniec, wędrowiec, pielgrzym, żebrak’ (objaśnienia za: SPXVI) w tekstach z tego okresu zostały poświadczone (kolejno) dwunasto- i czternastokrotnie, a na ich bazie (przynajmniej w ujęciu przedstawionym w SPXVI) rozwinęły się wtórne wartości semantyczne, świadczące o zaczynającej się dokonywać pejoratywizacji znaczenia, odpowiednio: 'natręt, faktor, stręczyciel, zalotnik' (potwierdzone dwa razy) oraz 'propagator fałszywych poglądów religijnych' (występujące w tekstach polemicznych, które wyszły spod pióra protestantów). Wydaje się, że punktem wyjścia do rozwoju tego ostatniego znaczenia był raczej notowany w SStp sens 'odstępca, apostata', którego w SPXVI jednak nie zarejestrowano. Zamiast niego pojawiaja się natomiast dwa nowe: 'zbieg' (zawężony też do: 'poddany polski przebywający stale w Rzymie a mający beneficjum w Polsce') oraz 'biegacz, zawodnik w biegach' (zob. SPXVI, https://spxvi.edu.pl/in deks/haslo/43907 [dostęp: 2.02.2020]). Wartość semantyczna 'obieżyświat, włóczęga' była dominująca jeszcze w XVII wieku, jak o tym zaświadcza Thesaurus polono-latino-graecus Grzegorza Knapiusza, w którym wyraz biegun objaśniono najpierw jako (podaję w transliteracji): „błakácz, wszedy był, powśinogá (...) obbiegácz (...) [który - dop. M.M] nie zagrzeie mieysca”. Ponadto słownikarz zarejestrował w swoim dziele dwa znaczenia nieodnoszące się do osób: „czopek, wáłek, ná ktorym sie co obraca” oraz „oś niebieska, ábo punkty niebieskie na ktorych ábo koło ktorych iákoby świát sie obraca" (Knapiusz 1643, 27). O ile pierwsze z nich znano zapewne już wcześniej, na co wskazuje (nieuwzględniony w SPXVI) czwarty sens podany w Stowniku Bartlomieja z Bydgosz̨zy, tj. 'część wrót' (łac. cardo, una pars ostii) (zob. Kędelska, Kwilecka, Luczak, oprac., 1999, 76-77; Waniakowa 2002, 216), o tyle drugie - astronomiczne (dziś podstawowe) - przed XVII stuleciem było jeszcze zupełnie nieznane (Knapiusz notuje je jako pierwszy). Zgodnie

$21 \mathrm{~W}$ transliteracji: biegun a. nieustawiczny apostata. 
z przyjętą praktyką leksykograficzną każdą z wyodrębnionych wartości semantycznych autor opisywał w osobnym haśle.

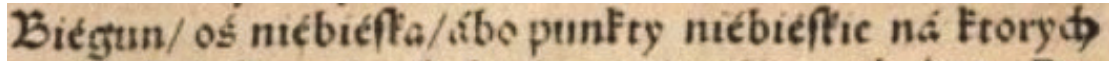 ábo foto ftoryd iáloby świât śic obraca/ó mín Go. Po-} lus, Cicer. Poli duo funt: Aréticus polus, Cicer. Pols necny/ ó zexlixoss. 1 Antareticus, Cuer. Poludmowy/

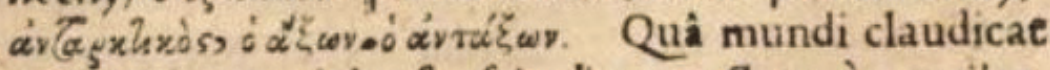
axis, Luiret. periphrafis, f. inclinatu est tr. à curribur. Antaxon, onis, Cic. Axis, Cicer: Ora quam nos incolimus fub axe.pofita ad ftellas feptem, Idem. Terram altricem noltram qux traiecto axi fuftinetur. $V \bar{a} a$ ośi ábe nä ośiád) wifâ. Vertex, Virg. Hic vertex nobis femper fublimis, at illum fub pedibus Styx atra videt. Cardo celorum, Vitr. Lucan. Oxid. Senec. Hippol.

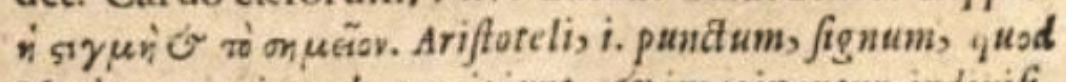
Matbematici in calo concipiant, $\mathcal{G}$ imaginantur indiaifibile, or nailam cali partem folidam occupans. Centrum c.xli, Plm.

Ryc. 1. Pierwsze w polskiej leksykografii poświadczenie znaczenia astronomicznego wyrazu biegun (fragment strony 27. z Thesaurusa... Knapiusza, wyd. pośmiertne z 1643 r.)

Nadmieńmy od razu, że to nowe, specjalistyczne znaczenie wyrazu biegun - w zgodnej opinii etymologów (zob. Sławski 1952-1956, 32; Bańkowski 2000, 48; Boryś 2005, 28; Mańczak 2017, 7) - jest kalką językową greckiego

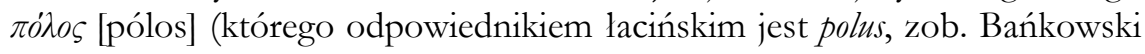
2000, 48). Czynnikiem, który umożliwił tę „przesiadkę semantyczną”, tj. przeniesienie sensu geograficznego z wyrazu greckiego na polski, była - jak dowodnie wykazała Jadwiga Waniakowa - „tożsamość znaczenia strukturalnego obu leksemów" (Waniakowa 2002, 221); każdy z nich można (było)

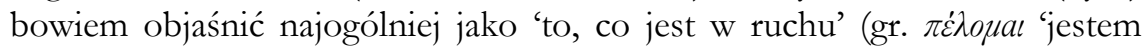
w ruchu').

O tym, że biegun jako termin astronomiczny w końcu XVI wieku nie był jeszcze używany, świadczy ewidentnie uwaga Jana Kochanowskiego wyrażona w następującym fragmencie dokonanego przezeń przekładu Phaenomenów (pol. Fenomenów) Aratosa (wyd. w Krakowie w 1585 roku): 
Wszytki gwiazdy tym pięknym wzorem usadzone

Pojmuje z sobą niebo nie ustanowione.

Sama oś, która prędki krąg niebieski toczy,

$\mathrm{Z}$ miejsca swego bynamniej nigdy nie wykroczy.

Ale trwa niewzruszona, ziemię przenikając:

A w poły prawie nieba oba końca mając

W szczepione (sic!), co imienia nie ma w naszej mowie,

Ale Polos i Greczyn i Rzymianin zowie.

Jeden $z$ nich na południe w morzu zatopiony,

A drugi na północy wzgórę wyniesiony.

(Kochanowski 1835, 136; podkr. - M.M.) 22

Wróćmy jednak do sensów osobowych rozpatrywanego rzeczownika. Z cała pewnością były one jeszcze żywe (a nawet dominowały nad znaczeniami nieosobowymi) w XVIII i XIX w., a niewykluczone, że również - na początku XX stulecia, jak wynika to z definicji leksemu biegun pomieszczonych w Nowym dykecjonarzu, to jest Mowniku polsko-francusko-niemieckim Michała Abrahama Trotza (Lipsk 1764), Stowniku jezyka polskiego Samuela Bogumiła Lindego (wyd. 1.: Warszawa 1807, wyd. 2.: Lwów 1854), Stowniku jezylka polskiego, tzw. wileńskim (Wilno 1861), a także Stowniku jezylka polskiego, tzw. warszawskim (Warszawa 1900). Nowy dykecjonarz... M.A. Trotza podaje w pierwszej kolejności następujące wartości semantyczne wyrazu biegun:

- 'goniec, posłaniec pana, suwerena';

- 'włóczęga, który chodzi z miejsca na miejsce';

- 'kurier, doręczyciel listów' (zob. Trotz 1764, 43-44).

Dopiero po nich następują znaczenia nieodnoszące się do osób: dwa techniczne i jedno geograficzne, tj.:

- 'sworzeń, oś; czop, zawias';

- geogr. 'biegun (np. ziemski); oś (obrotu, symetrii, Ziemi)';

- 'nakrętka śruby; otwór, do którego wkręca się śrubę (w którym kręci się śruba)' (zob. Trotz 1764, 43-44)23.

22 Fragment ten przytacza również w swoim artykule Waniakowa $(2002,215)$.

23 Jak wiadomo, jedną z cech wyróżniających Nowy dykecjonarz... M.A. Trotza jest porządkowanie znaczeń w obrębie artykułu hasłowego: od sensu najpowszechniejszego do znaczeń drugorzędnych i rzadkich (Żmigrodzki 2005, 133). W tym miejscu chciałbym serdecznie podziękować romanistce, dr Annie Gałęziowskiej-Krzystolik za przetłumaczenie objaśnień francuskich leksemu biegun zawartych w STr. Dzięki temu mogłem stwierdzić ich zgodność semantyczną z podanymi w słowniku odpowiednikami niemieckimi oraz najbardziej typowymi przykładami użycia w języku polskim. 
Należy zauważyć, że notowany w słownikach historycznojęzykowych, dokumentujących polszczyznę doby średniowiecza i renesansu, tj. w SStp oraz SPXVI, sens 'cursor' został w Nowym dykecjonarzu... - czy to z powodu skrupulatności leksykografa, czy też w związku z postępująca specjalizacją znaczeniowa, a może obu tych czynników zarazem - rozdzielony na dwa, z których ten oznaczony numerem 1. jest ogólniejszy ('goniec, czyjś posłaniec'), natomiast ten podany jako 3. jest nieco węższy (por. 'goniec, doręczający listy')24.

\begin{abstract}
rillon, gond. 5) géog. un pole; un axe. 6) écrouë; la femelle d'un vis; trou dans lequel tourne le vis. ( 1 ) za bieguna służy. 2) takich biegunow dofyć na śviećie. *3) poftaray śię o bieguna. (icdnacza) 4) bicgun ieft punkt, w ktorym śię co obracać może; biegun na ktorym chodzi kolowrot fzalny. 5) biegun albo oś niebicfka; biegun połnocny $\mathrm{i}$ potudniowy $\mathfrak{f}_{3}$ diva punkta, na ktorych șię niby swiat obraca. 6) biegun po wale prafuym chodźi.
\end{abstract}

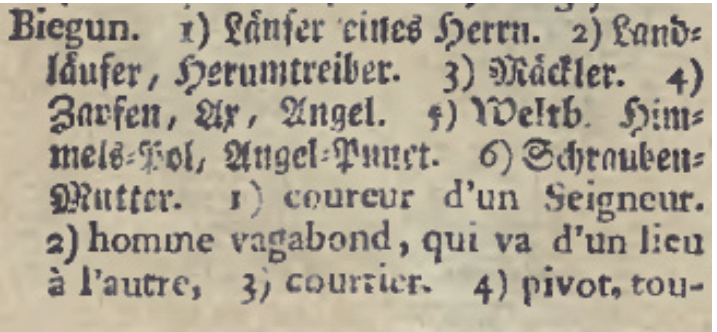

Ryc. 2. Hasło biegun w Nomym dykecjonarzu... M.A. Trotza (Trotz 1764, 43-44)

Stownik jezylka polskiego Samuela Bogumiła Lindego wysuwa na plan pierwszy wartość semantyczną 'biegacz, prędkonogi', znaną już w wieku XVI25, nienotowaną natomiast w XVII-wiecznym Thesaurusie... Knapiusza i XVIII-wiecznym Mowniku... Trotza. Dopiero jako drugie podaje Linde znaczenie 'biegający za zapłatę, kursor, laufer', przywołując przy nim przysłowie: Biegun biegunowi droge zajdzie, a poset spotka sie z.postem. W dalszej kolejności wymienia, nierejestrowany przez jego poprzedników, sens: 'koń biegun, woźnik, rumak', po którym następują dwa kolejne, poświadczone już dawniej (odpowiednio: w dobie staropolskiej oraz w XVI stuleciu), znaczenia: 'biegun, wszędobył, włóczęga, powsinoga, tułacz' oraz 'biegun, machlerz, faktor, stręczyciel, jednacz'. Po nich dopiero wylicza słownikarz trzy sensy nie-

${ }^{24} \mathrm{Na}$ dokonującą się z całą pewnością od XVI w. (a może już wcześniej?) specjalizację znaczenia leksemu BIEGUN, czego skutkiem było wykształcenie się zawężonej wartości semantycznej 'doręczyciel listów', funkcjonującej obok ogólniejszego sensu 'goniec, posłaniec', wskazują też objaśnienia łacińskich wyrazów cursor i tabellarius w słowniku Jana Mączyńskiego, w którym odpowiednikiem tego pierwszego jest właśnie „Kurfor/ Biegun/ lákáj” (Mączyński 1564, 73d), a ekwiwalentem drugiego - „Pofeł/ kurfor/ Biegun którego ślią s lifty/ liftownik" (Mączyński 1564, 438a).

25 Uwzględnia ją Lexicon latino-polonicum... Mączyńskiego, w którym łacińskie słowo stadioromos objaśniono jako „Zawodnik/ curfor/ biegun/ wyśćigácz” (Mączyński 1564, 411d). 
osobowe, uwzględnione wcześniej w Nowym dykejonarzu... Trotza, tj.: 'czop, czopek, wałek, na którym się co obraca, (sic!) lub biega, oś' (w tym także 'biegun młynarski, paprzyca' oraz 'drugi pacierz szyi'), 'oś niebieska abo punkta niebieskie, koło których jakoby świat się obraca' oraz 'biegun u szruby, macica' (Linde 1807, 102-103; Linde 1854, 104).

Układ znaczeń leksemu biegun, odnotowanych w Stowniku jezyka polskiego, tzw. wileńskim (SWil), a także Stowniku jezyka polskiego, tzw. warszawskim (SW) nie różni się w istotny sposób od podanego w Stowniku Lindego (SL). Sensy odnoszące się do ludzi oraz znaczenie 'rumak' w dalszym ciagu dominują nad użyciami specjalistycznymi (naukowymi, technicznymi), których jest tu więcej niż w SL. W SWil pojawia się ponadto nowa wartość osobowa: 'odszukiwacz koni i skradzionych rzeczy', z która - jak się zdaje - w SW koresponduje treść: 'ajent policji śledczej, rub. łapacz'; za to znaczenie 'mekler, faktor, stręczyciel, pośrednik, jednacz’ skrupulatni autorzy SW opatrzyli krzyżykiem, uznając je za „mało używane”. Wśród sensów nieosobowych, zarejestrowanych $\mathrm{w}$ obu leksykonach, znalazła się m.in. nienotowana przez wcześniejszych słownikarzy (a istniejąca do dziś) wartość semantyczna 'jedna $z$ dwu łukowatych (półokragłych) płóz u kołysek, foteli, koników drewnianych, dzięki którym się one kołyszą, bujają'. Mniej więcej od drugiej połowy XIX wieku - jak można stwierdzić na podstawie SWil i SW - biegun zaczyna funkcjonować również w dyskursie flisackim (w którym oznacza tzw. chlubownicę, czyli 'kół na 10 stop długi, 5 cali gruby, w ziemię wbity, który służy do biegania, czyli skręcania wici’; definicja za: SWil), matematycznym (m.in. biegun koła lub kuli, biegun prostej wagledem kraywej), fizycznym (bieguny magnesu) oraz w logice ('dwa pojęcia sobie przeciwne i krańcami ostatecznemi czegoś będące’; za: SWil).

Istotne zmiany $\mathrm{w}$ semantyce omawianego rzeczownika nastapiły dopiero w ciągu XX stulecia. Wszystkie znaczenia osobowe, w których biegun używany był poprzednio, odeszły wówczas w niepamięć: współczesne słowniki ogólne języka polskiego, począwszy od SJPD aż po WSJP, uwzględniają wyłącznie jego sensy nieosobowe. Jedynie w Suplemencie do SJPD zarejestrowano dawną, choć - zaznaczmy - nienotowaną w żadnym z wcześniejszych słowników, wartość semantyczną: 'rzemieślnik niecechowy, wykonujący rzemiosło bez zezwolenia cechu; partacz, sturzarz', ilustrując ją tylko jednym przykładem użycia, pochodzącym notabene z XIX-wiecznego (!) opracowania naukowego autorstwa Michała Balińskiego i Tymoteusza Lipińskiego pt. Starosytna Polska pod wagledem historycznym, geograficznym i statystycznym, zob.: „Królewic Jakub Ludwik Sobieski, ponawiając w 1727 r. ustawy cechu kusz- 
nierskiego [kuśnierskiego] i krawieckiego, zabrania sturzarzom, czyli partaczom albo biegunom, trudnić się robotą na mil 2 od miasta” (cyt. za: Doroszewski, red., 1969, 50). Żywotność poszczególnych znaczeń osobowych leksemu biegun w polszczyźnie, możliwą do ustalenia na podstawie materiału leksykograficznego, poglądowo przedstawiono w tabeli 2.

Tabela 2. Żywotność znaczeń osobowych wyrazu biegun w historii polszczyzny na podstawie dawnych i współczesnych słowników języka polskiego ${ }^{26}$

\begin{tabular}{|l|c|c|c|c|c|c|c|c|}
\hline \multicolumn{1}{|c|}{ Wiek } & XV & XVI & XVII & XVIII & XIX & XIX & XIX & XX \\
\hline Znaczenie & SStp & SXVI & SKn & STr & SL & SWil & SW & SJPD \\
\hline 'włóczęga' & + & + & + & + & + & + & + & \\
\hline 'goniec' & + & + & & + & + & & + & \\
\hline 'odstępca' & + & + & & & & & & \\
\hline 'natręt' & & + & & & & & & \\
\hline 'zbieg' & & + & & & & & & \\
\hline 'pośrednik' & & $(+)$ & & & + & + & $(+)$ & \\
\hline 'biegacz' & & + & & & + & + & + & \\
\hline 'agent śledczy' & & & & & & + & + & \\
\hline $\begin{array}{l}\text { 'rzemieślnik } \\
\text { niecechowy' }\end{array}$ & & & & & & & & $(+)$ \\
\hline
\end{tabular}

Z zaprezentowanego zestawienia wynika, że wyraz biegun najdłużej, bo od XV wieku używany był w znaczeniach: 'włóczęga' oraz 'goniec'27, a następnie, od XVI stulecia - w znaczeniach: 'biegacz' i (zdecydowanie rzadziej) 'pośrednik'28. Pozostałe sensy osobowe, pojawiające się w różnych okresach rozwoju naszego języka, miały raczej charakter efemeryczny.

$\mathrm{Na}$ koniec trzeba zapytać o czynniki, które spowodowały, że leksem biegun przestał być używany w odniesieniu do ludzi. Wydaje się, iż przyczyn, które

26 Znak „,+” oznacza, że w danym leksykonie odnotowano wskazane znaczenie. Z kolei ten sam znak ujęty w nawias informuje, że autorzy słownika uznali jakiś sens za dawny lub rzadki. Zamalowane obszary obrazuja przypuszczalny okres, w którym poszczególne znaczenia osobowe były jeszcze żywe. Poza tym na podstawie dat ukazania się odpowiednich tomów SL, SWil i SW można przyjąć, że rejestrują one kolejno stan z początku (i pierwszej połowy) XIX wieku, połowy tego stulecia oraz jego końca (i drugiej połowy).

${ }^{27}$ Brak poświadczenia wartości semantycznej 'goniec' w SKn i SWil nie dowodzi bynajmniej jej wygaśnięcia w okresie, z którego te słowniki pochodzą, skoro notują ja jeszcze opracowania od nich późniejsze, odpowiednio: STr i SW.

${ }^{28}$ O tym, że sens 'pośrednik' był rzadki, może świadczyć fakt, iż w SXVI mamy zaledwie dwa jego poświadczenia; nie rejestruja go SKn i STr, również w SW opatrzony został stosownym kwalifikatorem. 
doprowadziły do takiego stanu rzeczy, mogło być kilka, przy czym dwie sa szczególnie istotne. Pierwszą jest dokonująca się stopniowo leksykalizacja omawianej jednostki; znaczenia osobowe stawały się nieczytelne, bo wyraz biegun tracił swoja przejrzystość słowotwórczą wskutek niewielkiej liczby derywatów z -un oraz znikomej produktywności tego formantu (nowe struktury z jego udziałem powstawały sporadycznie). Do rozluźnienia, a w konsekwencji zerwania więzi z podstawą biegać przyczyniło się też powstanie wielu sensów technicznych, wykształconych w wyniku uogólnienia i przeniesienia (na zasadzie metonimii) znaczenia pierwotnego (strukturalnego) bieguna: 'ten, co biega' $\rightarrow$ 'to, co biega' $\rightarrow$ 'to, co się porusza (co jest w ruchu)' $\rightarrow$ 'to, co podlega ruchowi' i 'to, co umożliwia ruch', nade wszystko zaś pojawienie się w XVII wieku skalkowanego z greki znaczenia geograficznego (astronomicznego), stanowiącego - jak się okazało - żyzny grunt dla rozwoju licznych znaczeń abstrakcyjnych, w których biegun używany jest w fizyce, matematyce, geometrii czy logice ${ }^{29}$ (por. Waniakowa 2002, 218-220). Drugim czynnikiem, który przyczynił się do wygaśnięcia sensów osobowych rozpatrywanej jednostki, było powstanie „konkurencyjnych” wobec bieguna formacji agentywnych derywowanych na bazie czasownika biegać za pomocą innych przyrostków - w XVI wieku słów: biegarz i biegacz, a później, tj. w XIX stuleciu, wyrazów: biegas i biegus. Spośród tych synonimów słowotwórczych „najgroźniejszy” okazał się biegacz ze względu na wykorzystany do jego utworzenia formant -acz, który od najdawniejszych czasów wyspecjalizowany był właśnie w derywowaniu odczasownikowych osobowych nazw wykonawców czynności; jego dwie pozostałe funkcje, tj. fundowanie nazw narzędzi i nazw znamionujących, były drugorzędne ${ }^{30}$ (zob. Pepłowski 1974, 12-13; Sławski 2011, 78-79). Nic więc dziwnego, że przejął on znaczenia osobowe

29 Pojawienie się znaczenia geograficznego (astronomicznego) było w moim przekonaniu kluczowym czynnikiem, który zadecydował o zerwaniu więzi analizowanego rzeczownika z czasownikiem biegać, a zarazem spowodował wejście bieguna na nowe tory rozwoju semantycznego: jak już wspomniano, wyraz zaczął obrastać w nowe, metaforyczne znaczenia - był to więc przysłowiowy „gwóźdź do trumny”, gdy idzie o leksykalizację omawianej jednostki.

30 Także wśród ok. 500 nazw wykonawców czynności z formantem -acz zarejestrowanych w SJPD znaczną grupę stanowią derywaty oznaczające subiekty osobowe. Sporo formacji tego typu łączy w sobie znaczenie osobowego wykonawcy czynności (działacza) i narzędzia, przy czym praktycznie każda nazwa narzędzia może być użyta też w odniesieniu do ludzi. Warto odnotować istotne przesunięcie, a mianowicie przejście z kategorii nomina agentis do kategorii nomina instrumenti, które dokonało się dopiero w ciagu minionego stulecia: „nazwy, które SW notuje jako odnoszące się do człowieka, dziś są na ogół nazwami narzędzi (np. przerywacz, popychacz)" (Grzegorczykowa, Laskowski, Wróbel, red., 1984, 342-343). 
leksemu biegun (zauważmy, że w przeciwieństwie do bieguna jego związek z podstawą biegać jest do dziś bardzo czytelny) ${ }^{31}$.

Wracając do stanowiącego punkt wyjścia niniejszych rozważań problemu motywacji tytułu powieści Olgi Tokarczuk Bieguni, wypada stwierdzić, że przeprowadzona analiza dowodzi, iż wywodzenie go od nazwy „odłamu prawosławnych starowierców" - jak sugeruje wydawca - nie jest (ani też być nie powinno) jedyną możliwością, zwłaszcza że sensu tego nie rejestruje w zasadzie żaden współczesny słownik języka polskiego ${ }^{32}$. Pisarka, tytułując w ten sposób swoje dzieło, w istocie wskrzesiła niektóre dawne znaczenia osobowe wyrazu biegun, wydobywając zarazem tkwiące w nim in potentia nowe, metaforyczne sensy - dokonała tym samym deleksykalizacji rozpatrywanej jednostki. Trudno tylko stwierdzić, czy i w jakim stopniu był to zabieg świadomy, celowy.

\section{Literatura}

Bańkowski A., 2000, Etymologiczny stownik jesylka polskiego, t. 1, Warszawa.

Boryś W., 2005, Stownik etymologičny jesykea polskiego, Kraków.

Brückner A., 1985, Stownik etymologičny jesylka polskiego, Warszawa.

Doroszewski W., red., 1958-1969, Stownik. jezykea polskiego PAN (SJPD), t. 1-11, Warszawa.

Elektroniczny stownik, jerykea polskiego XVII i XVIII wieku (ESJP XVII-XVIII), https://sxvii.pl/ [dostęp: 28.01.2020].

Erzepki B., 1908, Pryycrynki do średnioniecznego stownictwa polskiego, cz. 1, Glosy polskie wpisane do tacinsko-niemieckiego stownika (Nocabularius Ex quo) drukowanego w roku 1490, „Roczniki Towarzystwa Przyjaciół Nauk Poznańskiego”, t. XXXIV, https://www.wbc.poznan.pl/dlibra /publication/107676/edition/118792/content [dostęp: 1.02.2020].

Grzegorczykowa R., Laskowski R., Wróbel H., red., 1984, Gramatyka wspótczesnego jezyyka polskiego. Morfologia, Warszawa.

Jadacka H., 2006, Kultura jesylka polskiego. Fleksja, stowotwórstwo, składnia, Warszawa.

31 Gdy zaś idzie o znaczenie 'włóczęga', w którym biegun funkcjonował bodaj najdłużej i które nieprzerwanie notują wszystkie słowniki aż do SW, to dodatkowym czynnikiem, który zadecydował o jego wyjściu z użycia, mógł być fakt, iż liczba określeń homo vagus w polszczyźnie zawsze była dość spora, tym samym nie doszło do powstania żadnej luki leksykalnej. Przeglądu synonimów leksemu WŁÓCZĘGA w dziejach języka polskiego dokonała Beata Kisz$\mathrm{ka}(2013)$.

32 Znaczenie to udało mi się odnaleźć tylko w dostępnym w internecie Stowniku gramatycznym jezykea polskiego (zob. http://sgjp.pl/leksemy/\#83315/biegun [dostęp: 10.02.2020]). Za nim dopiero sens ten odnotowuje Stownik sjp.pl (zob. https://sjp.pl/biegun [dostęp: 10.02.2020]). Wydaje się jednak, że znaczenie to dopisano przy okazji aktualizacji wskazanych słowników (już po wydaniu powieści Tokarczuk). 
Karłowicz J., Kryński A., Niedźwiedzki W., red., 1900-1927, Stownik jezyłka polskiego (SW), t. 1-8, Warszawa.

Kędelska E., Kwilecka I., Luczak A., oprac., 1999, Stownik Barttomieja z. Bydgoszçy. Wersja polsko-tacińska, t. 1, Warszawa.

Kiszka B., 2013, Stowna wędrówka z biegunem, ceklownikiem $i$ wagusem... - w poszukiwaniu zaginionych synonimów leksemu włóczęga, w: Mitręga B., red., „Linguarum Silva”, t. 2, Słowoznaczenie - relacja w jezyku i tekśsie, Katowice.

Kleszczowa K., red., 1996, Stowotwórstwo jezylka doby staropolskiej. Przeglad formacji rzeczownikowych, Katowice.

Knapiusz G., 1643, Thesaurus polono-latino-graecus (SKn), Kraków, https://books.google.pl/ books?id=1AQ-AAAAcAAJ\&printsec=frontcover\&hl=pl\&source=gbs_ge_summary_r\&c $\mathrm{ad}=0 \#_{\mathrm{v}}=$ onepage $\& \mathrm{q} \& \mathrm{f}=$ false [dostęp: 2.02 .2020 ].

Kochanowski J., 1835, Phaenomena, w: Drieła Jana Kochanowskiego. Wydanie nowe Jana Nep. Bobrowicza, t. 3, Lipsk.

Kuligowska K., 2018, Narz̨edzie w polskiej i rosyjskiej przestrzeni kognitywnej, Poznań.

Łoś J., 1912, Mammotrekt z.r. 1471, „Materyały i Prace Komisyi Językowej Akademii Umiejętności w Krakowie", t. V.

Małecki A., oprac., 1871, Biblia królowej Zofii żony Jagiełty z kodeksu szaroszpatackiego naktadem księcia Jerzego Henryka Lubomirskiego wydana przez. Antoniego Mateckiego, Lwów, https://ar chive.org/details/bibliakrlowjzof00magoog/page/n9/mode/2up [dostęp: 2.02.2020].

Mańczak W., 2017, Polski stownik etymologiczny, Kraków.

Mayenowa M.R., Pepłowski F., red., 1966-2012, Stownik polsz̨ryzny XVI wieku (SPXVI), t. 136, Wrocław - Warszawa - Kraków (wersja elektroniczna: http://spxvi.edu.pl/indeks/).

Mączyński J., 1564, Lexicon latino-polonicum ex optimis Latinae linguae Scriptoribus concinnatum..., Królewiec, https://www.dbc.wroc.pl/dlibra/publication/8891/edition/8025/content [dostęp: 6.02.2020].

Olga Tokarczuk laureatka Międzynarodowej Nagrody Bookera, https://kultura.onet.pl/wiadomosci /olga-tokarczuk-laureatka-miedzynarodowej-nagro dy-bookera/vvwyrcg [dostęp: 29.01.2020].

Pepłowski F., 1974, Odczasownikowe naz̧yy wykonawców czynności w polsz̨çyźnie XVI wieku, Wrocław - Warszawa - Kraków - Gdańsk.

Radziwon M., 2008, Dwudriestke po raz dwudziesty, „Gazeta Wyborcza”, https://wybor cza.pl/1,75410,5217684,Dwudziestka_po_raz_dwunasty.html [dostęp: 29.01.2020].

Ruszkowski M., 2018, W ariantywność wspótczesnej polsz̧çyzny. Wybrane zagadnienia, Kielce.

Saloni Z., 1988, O trw. formach nieosobowych [rzeczowników] meskoosobowych we wspótczesnej polszçyżnie, „Biuletyn Polskiego Towarzystwa Językoznawczego”, z. XLI.

Sławski F., 1952-1956, Stownik etymologiczny jezyka polskiego, t. 1, Kraków.

Sławski F., 2011, Stowotwórstwo, stownictwo i etymologia stowiańska, Kraków.

Stownik gramatyczny jezy/ka polskiego, http://sgjp.pl/leksemy/\#13589/a [dostęp: 10.02.2020].

Stownik jezyke polskiego PWN, https://sjp.pwn.pl/ [dostęp: 28.01.2020].

Stownik sjp.pl, sjp.pl [dostęp: 10.02.2020].

Strutyński J., 1994, Zarys gramatyki polskiej, cz. 2, Morfologia, Kraków.

Tokarczuk O., 2007, Bieguni, Kraków.

Tokarczuk O., 2018, Bieguni, Kraków.

Trotz M.A., 1764, Nowy dykeyonarz to iest Mownik polsko-niemiecko-francuski (STr), Lipsk, https://www.dbc.wroc.pl/dlibra/publication/7823/edition/7138/content [dostęp: 2.02.2020]. 
Urbańczyk S., red., 1953-1955, Stownik staropolski (SStp), t. 1, Warszawa.

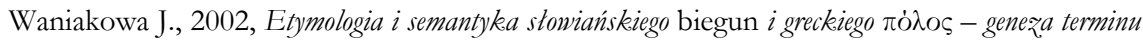
naukowego, w: Rusek J., Boryś W., Bednarczuk L., red., Drieje Stowian w świetle leksyki. Pamięci Profesora Franciszka Stawskiego, Kraków.

Waniakowa J., 2003a, Polska naukowa terminologia astronomiczna, Kraków.

Waniakowa J., 2003b, Wybrane najstarsz̨e polskie stownictwo astronomicz̨ne, „Język Polski”, nr LXXXIII, z. 2.

Wojtyła-Świerzowska M., 1974, Prasłowiańskie nomen agentis, Wrocław-Warszawa-KrakówGdańsk.

Zdanowicz A. (i in.), red., 1861, Stownik jezyke polskiego (SWil), t. 1-2, Wilno.

Żmigrodzki P., 2005, Wprowadzenie do leksykografii polskiej, Katowice.

Żmigrodzki P., red., Wielki stownik jesylka polskiego (WSJP), wsjp.pl [dostęp: 10.02.2020].

Zurawska-Górecka W., Kyas V., oprac., 1978, Mamotrekty staropolskie, cz. 2, Wrocław.

Maciołek Marcin - dr, Instytut Językoznawstwa, Uniwersytet Śląski w Katowicach, Polska.

Jego zainteresowania naukowe to: rozwój zasobu leksykalnego polszczyzny współczesnej i historycznej, wpływ techniki na ewolucję języka (zwłaszcza oddziaływanie rzeczywistości elektronicznej na język polski i zachowania komunikacyjne Polaków), historia i gramatyka historyczna języka polskiego, glottodydaktyka polonistyczna (przede wszystkim nauczanie wymowy polskiej cudzoziemców). Jest autorem książek: Obrazki do kształtowania percepcji słuchowej oraz wymowy cudzoziemców uczących się języka polskiego (2018), U źródeł słów (2017), Na tropie form i znaczeń słów (2015), Kształtowanie się nazw owadów w języku polskim. Procesy nominacyjne a językowy obraz świata (2013), Głoski polskie. Przewodnik fonetyczny dla cudzoziemców i nauczycieli uczących języka polskiego jako obcego (2012, wyd. drugie uzupełnione - 2014, wyd. trzecie rozszerzone - 2018) oraz kilkakrotnie wznawianego kompendium Tęczowa gramatyka języka polskiego w tabelach (2009, 2010, 2012, 2016), a także współredaktorem tomów: Ruch w języku - język w ruchu (2012), Granice w języku - język w granicach (2014), Społeczność w języku - język w społeczności (2019).

Kontakt: marcin.maciolek@us.edu.pl 